\title{
PSYCHOLOGICAL COUNSELLING OF PERSONALITY LIFESTYLE DEVELOPMENT
}

\section{Malyna O. G.}

\section{INTRODUCTION}

Clearly, modern psychology has the objective to enhance the development process of harmonious and psychologically healthy personality who can live their life efficiently and creatively in quite brutal and stressful living conditions. Personality lifestyle is one of the key terms that deal with successful practical realization of desired goal.

Lifestyle characterises the level of one's freedom in choosing social behaviour form and content and acts as a kind of personality's selfmanifestation, self-affirmation and self-realization and is defined as a "special individual approach of implementation of chosen by a personality way of living, set of behavioural patterns that are picking up consistently reproduced features, manners, tendencies, i.e. the way in which a person as a subject of life lives their life, as an individual and peculiar integral system of stable means and forms of personality's objective living conditions, that is formed on the basis of needs and abilities and is manifested in realization process of one's life goals and plans"1.

Style dynamics analysis helps acknowledge that particular lifestyles depict different level of human inherent activity, longing for psychological maturity, more difficult life activity organisation forms. In turn, it gives an opportunity to review certain lifestyle types as its development levels form the lowest level of personal maturity to the highest, where psychological characteristics of corresponding level are close to the description of a "healthy" harmonious personality.

Level and type analysis of personality lifestyle formation during youth years gave an opportunity to experimentally prove the statements about 1) the ability of lifestyle development, 2) correlation of the process with personality development age patterns, 3) youth sensitivity in personality lifestyle formation. However, methodological approaches and psychological means of personality lifestyle formation process optimization are still underdeveloped.

Therefore, the relevance of targeted psycho-pedagogical influences with the aim of optimising lifestyle development process at every age stage of its

\footnotetext{
${ }^{1}$ Титаренко Т.М. Життєвий світ особистості: у межах і за межами буденності [Текст] / Т.М. Титаренко. - К.: Либідь, 2003. - С 126
} 
formation is increasingly acknowledged. In our assessment, it is appropriate within the topic of psychological counselling of young personality formation in education system.

\section{Personality lifestyle: definition, structure, typology}

The issue of style manifestation and lifestyle in particular has become highly relevant in the recent times and is characterised by substantial scholarly interest. The relevance of style issue research is largely driven by the need of study of manifestation peculiarities of personality life activity and actual consideration (in practice as well as in scientific field) of instrumental part of a person's individuality. Peculiarity analysis of a person's life manifestation in different spheres of one's life and activity, action analysis, attitude towards oneself and other people, study of factors that contribute to socially useful creativity of a personality, promote solving a more general issue - formation of diverse individuality. In social and psychological aspect this issue can be analysed with the help of such psychological phenomenon as personality lifestyle.

According to structural-typological approach in style phenomenon research (Hrytchuk H.V., Dikova-Favorska O.M., Malyna O.G., Pylayeva T.B, Polivanova O.Y., Prykhodko T.V., Chmil L.B., Chuiko H.V., Shvalb Y.M.), a lifestyle is first of all the choice of "one's own way of living based on the determination of life priorities and orientations of axiological content with the aim of further self-manifestation in society"2.

To summarize the results of modern theoretical and empirical research it can be concluded that lifestyle is a structure that provides variability of live activity of people in society, determines the influence of social regulators on life activity, i.e. social and normative way of living and characterises the level of freedom in choosing social behaviour form and content and acts as a kind of self-manifestation, self-affirmation and self-realization of a person.

Thus, lifestyle acts as an integral system of sustainable means and forms of personality mediation of objective living conditions, that is formed on the basis of needs and abilities and manifests itself in the process of personality life goals and plans realisation. The major features of this system are: integral structure that is mediated by life activity determination of external and internal factors; correlation with integral life activity and its personal and social regulators; existence of a special core, which, so to speak, connects the diversity of life actions and creates unity, harmony, recognition of a person in

2 Приходько Т. В. Критерії дослідження стилів життя в парадигмах соціальної філософії URL: http://novyn.kpi.ua/2006-2/06_Prihotko.pdf 
all their deeds, actions, situations and gives a special character of existence to the life of a person ${ }^{3}$.

The study of lifestyle in the aspect of its formation inevitably leaves the question of correlation of this phenomenon with its holders, which it is a function of. In other words, which category - personality, individuality, subject - help discover psychological content of lifestyle to the fullest and what level of generality should one consider a person to realise their lifestyle. When analysing the issue of lifestyle formation we consider personality first of all as a subject, i.e. holder of substantive and practical activity and cognition, the source of activity directed to the object. V.O. Tatenko mentions that personal agency is observed in ability to: "goal setting" of one's psychological development and oneself as a regulator of this process; "choose", "find", "forecast" psychological means that one need to reach their goals; "decision-making" on when and under what circumstances the intended goal can be optimally reached by the chosen means; decision implementation; implemented result "assessment", success-failure reason analysis; "accumulation" of individual experience; "fixation" of the results and means of one's subjective qualities development ${ }^{4}$..

In the context of style issue research the category of a subject has always been presented a priori, because it is impossible to consider style as selfmanifestation of individual psychological activity, result of free and responsible decision-making beyond subjectivity. Lifestyle is the term that can define to the fullest extent personality life specifics, conditions and circumstances of personality formation, individual personality trait peculiarities, diversity of individuality, motivation and emotional-volitional sphere.

Thus, lifestyle acts as a special individual way of implementing the chosen by personality way of living and the way in which personality conducts their life, the way of manifesting a person in the world and the way of our interaction with the surrounding reality. Moreover, in this research personality lifestyle is considered as a forming element of this interaction. Structuraltypological analysis makes it possible to build a lifestyle model, find its structural and constituent components and appropriate criteria for lifestyle typology, provide them with relevant psychological content. According to

\footnotetext{
${ }^{3}$ Малина О.Г. Аналіз теоретичних підходів до поняття «стиль життя особистості» в психології. Проблеми сучасної психології: збірник наукових пращь Державного вищого навчального закладу “Запорізький національний університет” та Інституту психології імені Г.С. Костюка НАПН України / За ред. С.Д. Максименка, Н.Ф. Шевченко, М.Г. Ткалич. Запоріжжя:. 2018. № № 2 (14). С. 72-78.

${ }^{4}$ Татенко В.О. Людина. Суб'єкт. Вчинок: Філософсько-психологічні студії / за заг. ред. В.О. Татенка. К.: Либідь, 2006, С. 316-358.
} 
structural-typological analysis, personality lifestyle is a complex multilevel system, which includes such structural components as activity and personality orientation. The term of style appeared from the need to explain manifestation of different activity of people, when dealing with certain issues, which depends on external as well as internal factors. When analysing the nature of style, V.I. Morosanova states that style becomes a style when a determined activity occurs ${ }^{5}$. In that case, lifestyle is an individual and specific manifestation and form of activity that occurs in a determined system.

The modern view of the personality activity comes from the understanding of a personality as means of interaction of the subject with surrounding world, as a way of self-manifestation and self-realization of personality in life, in which one achieves (or not) the quality of a holistic, independent and capable to develop subject.

It is true that such indicators as social behaviour activity level in one area or another play an important role when characterising personality lifestyle. Moreover lifestyle typology requires intensity level of personality selfrealization process in one or type of life activity or another and in the context of the whole life activity at large.

However, lifestyle typology should take into consideration not only external formal characteristics, but also its content, personality values and orientation. This is the question of towards what activity is oriented i.e. personality activity vector.

V.A. Semychenko suggests that it is orientation as a combination of determinants that prompt and regulate human mental activity and acts as the most important component of internal psychological structure. In some way, it transforms all human deeds and actions, ways of manifesting one's mental abilities and qualities, "starts a certain form of human activity" and "connects in one whole all parts of complex mental processes" defines personality psychological state, with the help of orientation a goal manifests itself, which personality follows, their motifs, their subjective attitude towards various aspects of life activity.

Humans understand that they depend on what they need or what they are interested in. This understanding explains orientation towards a certain object, prompts and directs their activity. Thus, the issue of orientation is first of all the question about dynamic tendencies that contribute to human activity that

\footnotetext{
${ }^{5}$ Стиль человека: психологический анализ / Под ред. А.В. Либина. М.: Смысл, 1998, C. 185.

6 Семиченко В.А. Проблемы мотивации поведения и деятельности человека. Модульный курс психологии. Модуль «Направленность» [Текст]: Лекции, практические занятия, задания для самостоятельной работы / В.А. Семиченко - К.: Миллениум, 2004. C. 3-4.
} 
themselves are described by human goals and objectives. This is why we consider orientation an important feature that helps define the major tendencies of personality life activity and lifestyle in particular.

Considering lifestyle structure analysis, this research has defined personality activity and orientation as factors of its establishment. Moreover, activity is considered as level of subject interaction with surrounding world, the way of personality self-manifestation and self-realization in life, that helps achieve the quality of a holistic, independent and capable to develop subject. Personality orientation as a factor of personality lifestyle formation is considered as a stable dominating system of motivations, personality modus, one's structure core that depicts a dominant that becomes behavioural vector. Personality activity and orientation as personality lifestyle typology criteria were represented through such indicators: activity criterion - control locus, initiative, independence, rigidity, general activity, success motivation or failure prevention motivation; orientation criterion - ideas focused on altruism-egoism, and working process - work result, personality orientation towards oneself, towards interaction, towards the work.

Correlation of activity level and personality orientation type create a certain style type. According to the level and activity peculiarities (high, situational, low) and orientation type (individualistic, collective, inherent value and practical) the following types of lifestyle are theoretically defined: passive-individualistic, situational-individualistic, active-individualistic, passive-collective, situational-collective, active-collective, inherent value and practical passive, inherent value and practical situational and inherent value and practical active (creative).

\section{Personality lifestyle development peculiarities in ontogenesis}

As every other system, lifestyle retains its integral form within each type however it does not exclude the possibility of its development as a personality development manifestation. Personality lifestyle formation characterises style variability, particularly its development, an ongoing transformation of the quality that corresponds to the one (lowest) level into something different, i.e. the quality that corresponds to the highest level of the way of personality life activity organization. Thus, lifestyle is considered as behavioural forms, freely decided upon by personality as a subject of one's own life, that are diagonally opposed to explicit result from social behaviour and activity, i.e. in contrast to lifestyle, which is first of all characterized by social and historical determination of forms and means of behaviour. Bekh I.D. ${ }^{7}$ highlights that it

${ }^{7}$ Бех І.Д. Вибрані наукові праці. Виховання особистості / І.Д. Бех // Вибрані наукові праці: у 2 т.: Т. 1. Чернівці: Букрек, 2015. С. 63. 
is the process and result of personality's conscious decision of one or another possibility among their variety, "process of individual creation of conditions and means of life activity, and in the end, means of one's personal selfmanifestation and self-realization".

Considering the major features of lifestyle and ontogenetic ways of its development, it is possible to mention that this psychological phenomenon as an integral characteristic of subject life activity and means of one's interaction with the world is formed during the process of life, personal, social and professional self-manifestation and should become the result of one's successful realization.

That is why youth years play an important role as the most sensitive period of age development for lifestyle establishment.

Experimental research was focused on 1) definition of personality lifestyle typology and finding of statistically correct indicators for each type, description of substantial psychological characteristics ("portrait") of every one of nine theoretically constructed lifestyle types; 2) representation examination and distribution of outlined types among teenagers aged 14-15, high school students aged 16-17 and student youth aged 20-21;3) age dynamics analysis of type distribution by age groups. Sample analysis was made up of 337 people of Zaporizhzhia schools № 11, 3, 9 and schools with judicial training № 47 and 9 and Zaporizhzhia National University students. Theoretically constructed lifestyle types were experimentally studied with the help of complex of psychodiagnostic methods. The following bibliographies were used to study personality orientation peculiarities and personality activity parameters: questionnaire "Activity Threshold" (T. Romanova), "Psychological analysis of volitional power development" (B. Smirnov) (the scale), "Initiative and independence", "Psychological rigidity diagnostic scale" (G. Aizenko), "J. Rotter's Locus of Control" (modification of O. Yelisyeev), questionnaire "Success motivation and fear of failure" (A. Rehan), "Personality social and psychological diagnostic in motivational and need sphere" (O. Potyomkina), methodology "Personality orientation" (V. Smyekal and M. Kucher). "Interpersonal diagnosis", methodology of T. Lori, was used to take into account personality characterological features, define behavioural tendencies and interpersonal interaction strategy.

To bring together the data received, let us introduce short characteristics of personality lifestyle types for youth years:

Passive-individualistic (I) lifestyle type - is determined by the leading orientation of its representatives towards meeting one's egoistic needs, the main motifs are orientation towards one's well-being, desire for external success and prestige. People with such lifestyle type view other people only as means to reach one's own goals and desires. Their behaviour is egoistic, 
impolite and infantile. Representatives of this lifestyle type's activity is determined by anticipation of bad consequences; people with such lifestyle type are of little initiative, undisciplined and prone to plan their future for a short period of time. In general, this lifestyle type can be described as consumerist.

Situational-individualistic (II) type is characterised by unstable activity and lack of independence, ambitiousness, they are hot-headed, unable to control, plan and organise one's life. People of situational-individualistic lifestyle type are characterised by rigidity, lack of self-confidence and imbalance. On the outside they give an impression of chaotic search activity however it is only skin-deep. They do not have regular interests, hobbies or commitments. They are oriented towards maintaining one's own safety and in the majority of cases "go with the flow".

Active-individualistic (III) lifestyle type manifests itself in strong actions, high flexibility and creativity. However it is aimed at one's egoistic interests. People of such lifestyle type can be characterised by confidence, internality, independence, optimism, high self-esteem, ability to change success strategies quite easily. They perceive surrounding world as a stage for realization of one's own ego. These people are successful, skilful and self-confident.

Passive-collectivistic (IV) lifestyle type is prone to life in one's own world, introvert way of living, following the traditions, rituals, orientation towards group norms and values without any criticism. That is why representatives of such lifestyle type are easily influenced and under certain (bad) conditions are in danger of getting into social risk group. They avoid making responsible decisions, they are passive and pessimistic. The major psychological features of this type are compliance, trust and submission, that gives every reason to assume that this is a conformist and dependable lifestyle type.

Situational-collectivistic (V) lifestyle type can be determined by such dominating motifs as communication and meeting the needs of mutual sympathy. This type's activity depends on circumstances, mood, interest and is mostly encouraged by motivation of fear of failure. Representatives of such type set unreasonably impossible goals and inadequately evaluate their possibilities. They are insistable, initiative but lack independence. This lifestyle type is humanist, altruistic, benevolent but inactive because they are unsure of one's possibilities.

Active-collectivistic (VI) lifestyle type can be explained by the main selfrealization concept "to give the life to the people". It is characterised by high level of activity, initiative and independence, longing for active way of living and hig-intencity life activity as s whole. Personality of such lifestyle is kind, altruistic, self-confident and can be seen as a group leader. 
Inherent value and practical passive (VII) lifestyle type - representatives of such lifestyle type are initiative but indecisive. The main motifs of their lives is desire to perform their own thing as best as they can, their activity depends on their success. They are insisting, able to overcome the challenges but rigid, inert, private, prone to monotonous scrupulous work and seek emotional support and control from the management. Typical representative of such type would be an executor.

Inherent value and practical situational lifestyle type (VIII) is characterised by pragmatic orientation of its representatives, their social responsibility, morality, tendency to leadership. However their activity is unstable, chaotic and is determined by dominating interests at that time.

Inherent value and practical active lifestyle type (IX) can be seen in people who are fully matured as a personality, prone to self-affirmation, psychologically healthy individuals with high level of creativity and selfrealization. They choose constructive transforming strategies, have optimistic worldview, positive self-esteem, realistic approach to life and bright motivation to reach one's goals. This type can be characterised as creative.

Based on the type distribution analysis in different age groups it is possible to observe that such lifestyle types as situational-individualistic, passive- and situational-collectivistic are predominant among teenagers. These lifestyle types belong to the groups with low and average development level, which indicates the beginning stage of personality lifestyle formation. The major collectivistic orientation $(51,9 \%)$ in teenage lifestyle structure can be explained by age peculiarities of personality development. That is orientation towards communication with peers, need for self-respect and self-affirmation that reflects in positive attitude among friends. The dominance of lifestyle types with low or unstable activity parameters $(97 \%)$ can be explained by orientation towards the future, emergence of long-term plans, distant goals but denial of intended goal because of weak will and self-regulation skills.

The same lifestyle types are typical for high school students however their distribution is different - the percentage of passive-collectivistic lifestyle type drops significantly, that may be an indicator of visible development of selfconsciousness, independence, self-esteem, realization of one's individuality. The percentage of lifestyle types (comparing to the teenagers) with inherent value and practical orientation substantially increases, that may reflect the influence of such age formations as professional and life self-realization, desire to self growth, to set life plans, professionalisation of interests.

The student youth years observe a tendency of significant increase of lifestyle types with inherent value and practical orientation $(22 \%)$ and high level of activity $(73,2 \%)$, and vice versa, sharp drop of passive and individualistic lifestyles. That could be indicative of a new quality level of personal and style 
sphere development. Moreover, inherent value and practical active lifestyle type can be observed among university students, which by its characteristics is close to the definition of a healthy, harmonious self-assured personality. That means that a personality of such type has acquired a personal maturity in the process of successful life, personal and professional self-realization ${ }^{8}$.

The research results of teenagers and high school students reveal that these age groups lack or have the least represented types with high level activity and inherent value and practical personality orientation. The highest levels obtain types of individualistic and situational orientation, that to our mind can be explained by age peculiarities of personality development and in particular the importance of private-personal communication with peers, emergence of reflection, development of ego concept as new formations of such age groups.

The research results of university students reveal that this age group has the least represented types with low and high activity level and practical personality orientation. The highest levels obtained types of situational orientation, that to our mind can be explained by age peculiarities of personality development and in particular the importance of private-personal communication with peers, emergence of reflection, development of ego concept as new formations of such age groups.

According to the data collected, in each next age group there is a decreasing tendency in the amount of recipients who are among passiveindividualistic (1), situational-individualistic (2), passive-collectivistic (4) and situational-collectivistic (5) lifestyle types. And vice versa, university students have higher amount of recipients who are representatives of activeindividualistic (3), active-collectivistic (6), inherent value and practical passive (7), inherent value and practical situational (8) and inherent value and practical active (9) lifestyle types.

Situational-individualistic (2), passive-collectivistic (4) and situationalcollectivistic (5) lifestyles largely prevail, which decreases in proportion with the age and percentage of inherent value and practical passive (7), inherent value and practical situational (8) and inherent value and practical active (9) lifestyles is increasing steadily, percentage of activity and orientation towards the one's business is also increasing. This fact suggests that there is dynamics correlation between personality lifestyle and personal development, one's psychological and social maturity, tendencies to self-realization, actualisation of one's potential and personal and professional self-determination.

8 Діяльнісна самореалізація особистості в освітньому просторі: монографія / С.Д. Максименко, В.В. Бучма, О.В. Гурова [та ін.] ; за ред. С.Д. Максименка. Київ: Видавничий Дім «Слово», 2017. 242 с. ISBN 978-966-194-291-1. URL: http://lib.iitta.gov.ua/709731/ 


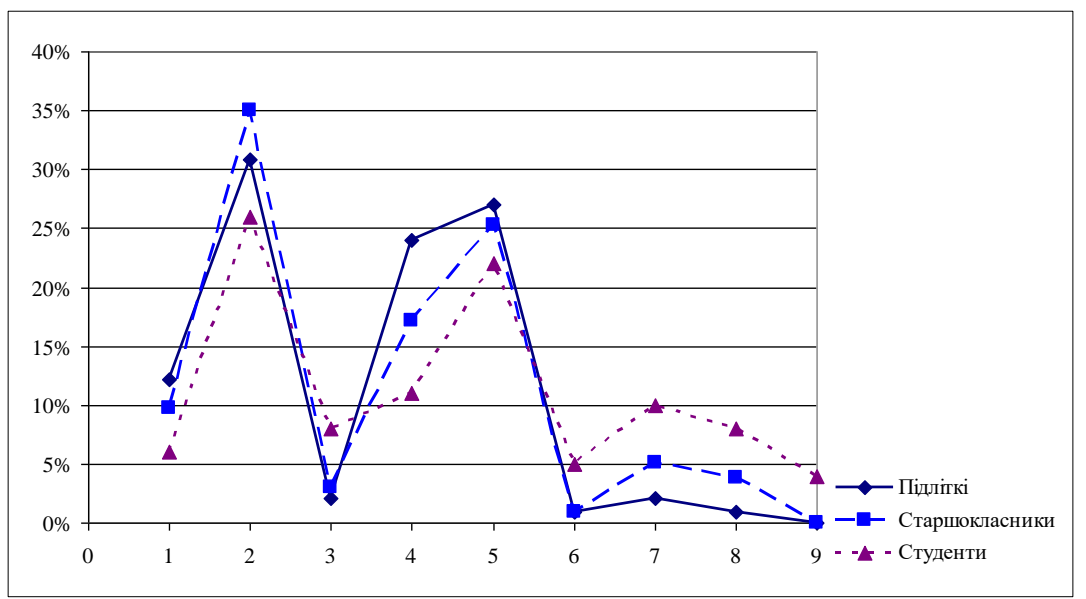

Fig. 1. Recipient style type distribution (percentage) in all age groups

According to the information received during the experiment, it is possible to conclude that:

- the first type, passive-individualistic, depending on the age (personality development level) is gradually decreasing in percentage terms (teenagers $12 \%$; high school students $-10 \%$; university students $-6 \%$ ). This could be indicative of the fact that this type is one of the early types in the process of personality lifestyle formation and with the age it (lifestyle) transforms into another higher one.

- the fourth type, passive-collectivistic, depending on the age also decreases gradually in percentage terms (teenagers $-24 \%$; high school students $-17 \%$; university students $-11 \%$ ). This could be indicative of the fact that the fourth type is also one of the first types in the process of personality lifestyle formation and with the age it (lifestyle) transforms into another higher one. Comparing this type to the first one, it is noticeable that percentage terms for the period between teenage and university student years the fourth type nearly doubles the first one (teenagers 1:12\%/4:24\%; high school students - 1:10\%/4:17\%; university students $-1: 6 \% / 4: 11 \%$ ). This could be an indicator that passive-collectivistic type is higher than passive-individualistic.

- the second type, situational-individualistic, in the period between teenage and university student years gains the highest percentage terms (teenagers $-31 \%$; high school students $-35 \%$; university students $-26 \%$ ).

- slightly fewer but still high indicators of percentage terms gains the fifth type, situational-collectivistic (teenagers - $27 \%$; high school students $25 \%$; university students $-22 \%$ ). These types are predominant during this age period. 
- the seventh type, inherent value and practical passive, occurs considerably less in this age period, however with the age percentage terms get higher (teenagers $-2 \%$; high school students $-5 \%$; university students $10 \%$ ). This could be indicative of a higher position on a relative scale in comparison to the second or the fifth personality lifestyle types.

- the third type, active-individualistic, during the considered age period has almost the same representation as the seventh (teenagers - $2 \%$; high school students $-3 \%$; university students $-8 \%$ ), however the percentage terms increase not as much that the seventh (teenagers $-3: 2 \% / 7: 2 \%$; high school students $-3: 3 \% / 7: 5 \%$; university students $-3: 8 \% / 7: 10 \%$ ).

- the sixth type, active-collectivistic, as well as the eighth, situationalpragmatic, has low representation in this age period (teenagers $-6: 1 \% / 8: 1 \%$; high school students $-6: 1 \% 8: 4 \%$; university students $-6: 5 \% / 8: 8 \%$ ).

- the ninth type, inherent value and practical active, in this age period is only represented among university students with low percentage ( teenagers $0 \%$; high school students $-0 \%$; university students $-4 \%$ ), that could be an indicator of the early formation stages of such type in this age period.

Psychological characteristics analysis of each lifestyle type and results of their ranking make it possible to describe their sequence in accordance with the development level. Successively they are distributed in the following way: passive-individualistic (1), passive-collectivistic (2), situational-individualistic (3), situational-collectivistic (4), inherent value and practical passive (5), active-individualistic (6), active-collectivistic (7), inherent value and practical situational (8), inherent value and practical active (9).

It is clear that the suggested sequence is, so to say, an ideal way of lifestyle development and heredity. In real life, humans may not always reach the highest levels of lifestyle development, it may not happen at all or may fluctuate in one or the other way. However it goes without saying that lifestyle development dynamics from passive-individualistic as consumerist, infantile and indifferent to active-practical (creative) as socially mature, self-confident and harmonious lifestyle depicts personality development in the direction towards self-actualisation and psychological health. This statement proves the detailed comparison of psychological characteristics of inherent value and practical active and creative lifestyle with the research of A. Maslow, G. Olport, K. Rodgers etc. considering personalities who want to become what they can become, which is self-actualisation.

\section{Remedial and developmental activities of personality lifestyle formation optimization}

Level and typology analysis of personality lifestyle formation during youth years gave a possibility to experimentally prove the statements about 1) the possibility of lifestyle development, 2) the dependence of the process 
on age characteristics of personality development, 3) the sensitivity of the youth years for personality lifestyle formation.

Therefore, there are reasons for realization of targeted psychologicalpedagogical influences with the aim of lifestyle development process optimization during each age period of its formation. To our mind, it is beneficial as a part of psychological-pedagogical counselling of young personality formation in the system of education.

Psychological-pedagogical counselling of personality lifestyle development and formation during youth years as a part of general personality development is, first of all, the system of psychologist professional activity. This activity aims at creating social-psychological conditions for successful psychological development of a young personality in the situation of real pedagogical interaction in education institutions, which is based on the following principles:

- unconditional evaluation of every student's inner world, prioritization of needs, goals and values of their development;

- creation of conditions for kids for independent creative learning of the system of relationship with the world and own ego, for independent and responsible making of personally valuable life choices by every student;

- creation of conditions for the highest personality development in the context of objective, certain social-pedagogical surrounding and consideration of the visible lifestyle development level and it's components, emergence of corresponding age formations ${ }^{9}$.

Psychological-pedagogical counselling of personality lifestyle formation in the youth years could be specified through solving such issues as:

1. Conducting education surrounding analysis (school, higher education institutions) with the teachers, considering the possibilities that it gives for personality lifestyle development in particular age period of personality formation and development.

2. Determination of psychological criteria for harmonious and logical lifestyle formation of young personality.

3. Organization and conduct of certain activities, forms and methods of work that can be considered useful for successful development of fully developed (according to the age) lifestyle.

4. Including these activities to the system of regular targeted work in order to receive a maximum result in each individual case.

Personality lifestyle development process optimization during youth years within psychological-pedagogical counselling is implemented through the

9 Становлення базових парадигм української психології: колективна монографія / В.В. Турбан, Л.3. Сердюк, Н.М. Бугайова [та ін.] ; за ред. В.В. Турбан, 2017. Київ: Видавничий Дім «Слово», 2017. 257 с. 
following approaches of education institution psychologist work: psychodiagnostic; remedial and developmental; counselling and educational. It is worth noting that suggested approaches of psychological-pedagogical counselling on lifestyle formation and development should comprise a coherent, consistent and targeted system of work with all subjects (students, teaching staff, parents, class or university student group) of young personality education process.

Forms of practical implementation of psychological-pedagogical counselling approaches to the process of personality lifestyle formation and development in the youth years:

Psychodiagnostic approach to psychological-pedagogical counselling is aimed at defining a certain personality lifestyle and identificating the development level of its major components for the future correction and development. When conducting diagnostic minimum (lifestyle type definition) it is possible to use methodologies "Activity Threshold" by T.A. Romanova to define personality activity level and "Personality Orientation" by V. Smyekala-M.Kucher to define personality orientation type of a student. The application of diagnostic minimum in lifestyle diagnosis is appropriate: 1) at the beginning of psychological-pedagogical counselling of lifestyle formation - during teenage years; 2 ) in big groups.

It is advisable to compare psychodiagnostic data with personality development age standards for future integration in developmental activities.

Remedial and developmental approach is the most complex, the biggest and the most time-consuming cluster of work in the context of psychologicalpedagogical counselling of lifestyle formation in as a part of general school education during the period of adolescent years. It is clear that certain lifestyle element correction is possible and important during the following stages of ontogenesis as well, however it is the most productive and promising within the school education in the process of targeted education programme, when personality may found oneself in a closer circle of developmental influences.

Remedial and developmental work includes active influence on personality with the aim of forming certain individual-psychological peculiarities that would be useful for one's subsequent lifestyle formation and development. The aim of remedial and developmental influence on personality lifestyle development optimization is determined by the understanding of ontogenetic patterns of lifestyle formation in the process of integral psychological development of a child as an active process that could be implemented in cooperation with an adult.

The major strategy of remedial and developmental approach to psychological-pedagogical counselling of personality lifestyle development is providing help that is oriented towards individual human peculiarities, one's 
specific possibilities and uniqueness of one's mental and personal development as a whole.

Thus, remedial and developmental work organization should be implemented in the context of the next statements:

1. The content of developmental work, first of all, corresponds with the lifestyle components, forming and complete development of which is the most important during this age period.

2. The content of developmental work, first of all, corresponds with the lifestyle components, which level does not correspond with the age standards and reveal problem areas that prevent personality development and are psychological determinants of lifestyle low level.

3. Remedial and developmental work should only be organised after the analysis of conducted psychodiagnostic cross-sections.

It was experimentally proven that activity and personality orientation are the major structural components of lifestyle. Moreover, it was statistically discovered that activity level plays a significant role in personality lifestyle development from the lowest to the highest levels. That is why remedial and developmental work should be aimed at increasing the personality activity level. However, we are of the view that the mechanism of this process should be correction of orientation and motivational and need spheres of a young personality. Thus, claim level gets higher through the implementation of needs. The awareness and implementation of these new claims leads to increase of the level and application of the new means of personality activity. Moreover, it is the motifs as a combination of external and internal conditions that provoke and direct activity of young personality as a lifestyle subject. In order to specify this statement, one should take into consideration that it is individualistic orientation of personality that needs correcting.

According to the content characteristics of each lifestyle type, apart from inherent value and practical active (9) as the highest level of development, certain style parameters are subject to the influence of remedial and developmental work, that is: egoistic worldview, failure rejection motifs, externality, rigidity, low level of initiative, independence, insecurity, weak will, negativity and alienation, compliance, conformism, insensitivity, low empathy level.

It is worth noting that every lifestyle development age stage (teenager, high school student, university student) of remedial and developmental influences needs certain structural components of lifestyle that correspond with age formation and development objectives. Their development and correction should be efficient, productive and relevant for harmonious personality lifestyle formation. 
It should be taken into account that integrity is the major notion for organisation and substantive content of remedial and developmental approach of psychological-pedagogical counselling of lifestyle formation and development process during youth years. That is to say that the content of remedial and developmental activities should provide holistic influence on the personality of a teenager, high school student or university student. In order to provide an efficient lifestyle development it is important to work with the personality as a whole, in all its diversity of motivational, emotional and behavioural approaches and not take into account certain problem areas of every lifestyle type that are prioritized for the primary correction and development.

The forms of remedial and developmental work are space organisation for psychological development (trainings, developmental meetings, implementation of psychological developmental techniques during lessons), implementation of correction programmes, that are specialized by age period, on the most important development issues and objectives of each lifestyle type that can be provided in the form of group (psychological training, psychological games, group discussions, role play, psychogymnastics) as well as individual activity.

Consulting and educational approach of psychological-pedagogical counselling of the personality lifestyle formation process during youth years is aimed at creating conditions for active learning and application of psychological knowledge by personality of a student, their parents and teachers in the process of lifestyle formation and development of every single personality. The forms of practical implementation of this approach may be educational courses, lectures, elective courses, discussions, individual consultations, psychological-pedagogical consilium.

The objectives of consulting and educational approach of psychologicalpedagogical counselling of subject lifestyle formation, i.e. teenager, high school student or university student, can be implemented through 1) helping students, that face difficulties in major determinant development of lifestyle and mental development of one's individuality; 2) teaching the selfunderstanding self-analysis techniques and implementation of one's psychological peculiarities for successful lifestyle and personal development.

Psychological consulting and education of teachers on student lifestyle development optimization is mostly appropriate to carry out in the form of psychological-pedagogical consilium. This gives an opportunity to build an equitable cooperation of the teacher and the psychologist on the basis of personal responsibility and organise an integral counselling of the students in the process of their education. All adults (teachers, parents, psychologists, school physicians) who are related to the process of student lifestyle formation 
and development should use their professional and personal potential on order to reinforce the results of this approach.

Consulting and educational work of psychologist with the parents in the context of psychological-pedagogical counselling of personality lifestyle formation process during youth years aims at creating conditions for including the family to the child counselling in the process of one's lifestyle formation. Thus, psychologist work is focused on creating the situation of cooperation, informing and forming the responsibility of the parents on problems and difficulties of individuality formation and development of a child.

\section{CONCLUSIONS}

Structural and typological model of personality lifestyle during youth years as a complex, multilevel, dynamic and systematic formation is represented by activity and orientation - strong dominating system of motivational formations that becomes behavioural vector. Dynamic patterns of type distribution by age groups (teenagers, high school students, university students) appear in decreasing number of recipients with passiveindividualistic, situational-individualistic, passive-collectivistic and situational-collectivistic lifestyle types and, vice versa, there has been an increase in representatives with active-individualistic, active-collectivistic, inherent value and practical passive, inherent value and practical situational and inherent value and practical active lifestyle types. General tendencies of type distribution are characterised by the dominance of individualistic and situational orientation types, that can be explained by personality development age peculiarities. Representatives of inherent value and practical active lifestyle type as the highest level of development can only be seen among university students, which is connected with successful personal and professional self-determination that is not typical for high school students and teenagers.

The described types are at the same time the stages of personality lifestyle development. There are mobile changes within every particular type, activity indicators are getting higher with the age, the percentage of collectivistic and inherent value and practical orientation increases, that corresponds with the age and personal development patterns. The results received make it clear that there is a great representation of lifestyle types with low and average development level and insufficient percentage of high development level lifestyle types. It has necessitated the search for ways of optimization of their development process, and it also explained the need to use systematic remedial and developmental influences with the aim of lifestyle development optimization during the sensitive period of its formation. 
Methodological approaches and ways of personality lifestyle formation process optimization during yputh years should focus on creating socialpsychological conditions for successful development of young personality in a situation of real pedagogical interaction in education institutions - in other words within the psychological counselling. Personality lifestyle development process optimization during youth years occurs in psychogymnastic, remedial and developmental, and consulting and educational approaches of work, that should constitute a targeted system of psychological support for all subjects of young personality education process with the aim of providing psychological help that is oriented towards human individual peculiarities, one's specific abilities and uniqueness of mental and personal development as a whole.

The study contributes, however not exhaust, to all the aspects of the outlined issue. Nevertheless, the issues of personality lifestyle development in adult years, analysis of lifestyle gender differences need further scientific development.

\section{SUMMARY}

The article reviews general principles of psychological counselling of personality lifestyle development process and describes the basic content of its approaches: psychodiagnostic, remedial and developmental, consulting and educational. The study is based on personality lifestyle phenomenon analysis, experimental research of its structure, typology and development levels. Special interest was drawn to the strategy, organisation, content and forms of correctional and developmental activities for lifestyle types with low development level. It was possible to define lifestyle parameters relevant for each type and formulate the objectives of remedial and developmental activities for personality lifestyle formation optimization. Age group type distribution analysis reflects correlation between personality lifestyle type dynamics and one's psychological and social maturity, tendencies to selfrealization actualisation of one's abilities and successful personal and professional self-determination.

\section{REFERENCES}

1. Титаренко Т.М. Життєвий світ особистості: у межах і за межами буденності. К.: Либідь, 2003. С. 126.

2. Приходько Т.В. Критерії дослідження стилів життя в парадигмах соціальної філософії URL: http://novyn.kpi.ua/2006-2/06_Prihotko.pdf

3. Малина О.Г. Аналіз теоретичних підходів до поняття “стиль життя особистості" в психології. Проблеми сучасної психології За ред. С.Д. Максименка, Н.Ф. Шевченко, М.Г. Ткалич. Запоріжжя:. 2018. № 2 (14). С. 72-78. 
4. Татенко В.О. Людина. Суб'єкт. Вчинок: Філософсько-психологічні студії / за заг. ред. В. О. Татенка. К.: Либідь, 2006, С 316-358.

5. Стиль человека: психологический анализ / Под ред. А.В. Либина. М.: Смысл, 1998, С. 185.

6. Семиченко В.А. Проблемы мотивации поведения и деятельности человека. Модульный курс психологии. Модуль "Направленность": Лекиии, практические занятия, задания для самостоятельной работы / В.А. Семиченко. К.: Миллениум, 2004. С. 3-4.

7. Бех І. Д. Вибрані наукові праці. Виховання особистості / Вибрані наукові праиі: у 2 т.: Т. 1. Чернівці: Букрек, 2015. С. 63.

8. Діяльнісна самореалізація особистості в освітньому просторі: монографія / за ред. С.Д. Максименка. Київ: Видавничий Дім "Слово", 2017. 242 c. ISBN 978-966-194-291-1. URL: http://lib.iitta.gov.ua/709731

9. Становлення базових парадигм української психології: колективна монографія / за ред. В.В. Турбан, 2017. Київ: Видавничий Дім “Слово”, 2017. 257 с.

\section{Information about the author:} Malyna O. G.,

Candidate of Psychological Science, Associate Professor at the Department of Psychology, Zaporizhzhia National University 66, Zhukovskoho str., Zaporizhzhia, 69600, Ukraine 